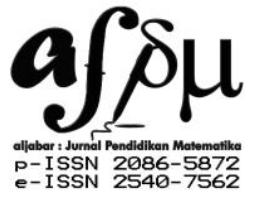

Al-Jabar: Jurnal Pendidikan Matematika

Vol. 8, No. 1, 2017, Hal 73 - 80

\title{
Eksperimentasi Pendekatan Kontekstual Berbantuan Hands On Activity (HoA) Terhadap Kemampuan Pemecahan Masalah Matematik
}

\author{
Fredi Ganda Putra \\ UIN Raden Intan Lampung: fredigpsw@gmail.com
}

\begin{abstract}
This study aims to determine the effect of contextual approaches assisted by Hands On Activity (HoA) on mathematical problem solving abilities. This research is comparative causal research with factorial design $3 \times 1$. The population of this research is all students of class VIII SMP Negeri 1 Simpang Semarang. Sampling was done by cluster random sampling. The sample of this research is students of class VIII B and VIII D. The instrument used to collect data is a test of mathematical problem solving ability of learners. Prior to use for data retrieval, the test instrument of mathematical problem solving ability was first tested. Assessment of validity of test instrument contents by 3 validators. Hypothesis test using two way Anova test with unequal cell. The conclusion of this research is that learners who get the application of contextual learning model with Hands on Activity has better problem solving ability than students who are given contextual learning model and conventional learning model, while the application of contextual learning model has better problem solving ability than the participants Students provided a contextual learning model and conventional learning model.
\end{abstract}

Keywords: contextual; HoA; problem; solve.

\begin{abstract}
Abstrak
Penelitian ini bertujuan untuk mengetahui pengaruh pendekatan kontekstual berbantuan Hands On Activity (HoA) terhadap kemampuan pemecahan masalah matematik. Penelitian ini merupakan penelitian kausal komparatif dengan desain faktorial $3 \times 1$. Populasi penelitian ini adalah seluruh peserta didik kelas VIII SMP Negeri 1 Simpang Pematang. Pengambilan sampel dilakukan dengan cluster random sampling. Sampel penelitian ini yaitu peserta didik kelas VIII B dan VIII D. Instrumen yang digunakan untuk mengumpulkan data adalah tes kemampuan pemecahan masalah matematis peserta didik. Sebelum digunakan untuk pengambilan data, instrumen tes kemampuan pemecahan masalah matematis terlebih dahulu diujicobakan. Penilaian validitas isi instrumen tes oleh 3 orang validator. Uji hipotesis menggunakan uji Anava dua jalan dengan sel tak sama. Kesimpulan penelitian ini adalah Peserta didik yang mendapatkan penerapan model pembelajaran kontekstual berbantuan Hands on Activity memiliki kemampuan pemecahan masalah matematis lebih baik dibandingkan peserta didik yang diberikan model pembelajaran kontekstual dan model pembelajaran konvensional, sedangkan penerapan model pembelajaran kontekstual memiliki kemampuan pemecahan masalah matematis lebih baik dibandingkan peserta didik yang diberikan model pembelajaran kontekstual dan model pembelajaran konvensional.
\end{abstract}

Kata Kunci: HoA; kontektual; masalah; pemecahan. 


\section{PENDAHULUAN}

Mempelajari matematika tidak hanya memahami konsepnya saja atau prosedurnya saja, akan tetapi banyak hal yang dapat muncul dari hasil proses pembelajaran matematika. Kebermaknaan dalam belajar matematika ditandai dengan kesadaran apa yang dilakukan, apa yang dipahami dan apa yang tidak dipahami oleh peserta didik tentang fakta, konsep, relasi, dan prosedur matematika. Cara dalam menyelesaikan masalah yang diperoleh peserta didik adalah hasil dari pengetahuan dan pengalaman yang dimiliki peserta didik terkait dengan masalah yang ingin dicari penyelesaiannya (Mawaddah \& Anisah, 2015). Oleh karena itu, seorang tenaga pengajar dituntut untuk mampu membantu peserta didik dalam memberikan kebermaknaan dalam belajar matematika. Kebermaknaan dalam proses pembelajaran merupakan salah satu cara agar peserta didik memiliki kemampuan pemecahan masalah matematis yang baik.

Agar peserta didik mampu untuk memecahkan masalah yang dihadapi dalam kegiatan belajar, maka peserta didik harus lebih tekun dan giat dalam belajarnya, karena masalah yang dihadapi peserta didik dalam kegiatan belajar tidak akan dicapai tanpa adanya usaha sendiri. Hal ini sebagaimana Firman Allah SWT dalam surat An-Najm sebagai berikut:

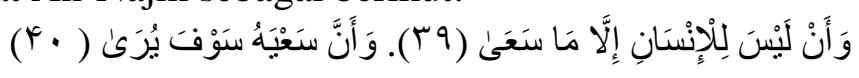

Artinya :

"dan bahwasanya seorang manusia tiada memperoleh selain apa yang telah diusahakannya. Dan bahwasanya usahanya itu kelak akan diperlihatkan (kepadanya).(QS. An-Najm: 39-40)".

Mengingat setiap peserta didik mempunyai taraf berpikir yang berbeda dan adanya kesulitan peserta didik dalam memecahkan masalah, maka keterampilan dan keahlian yang dimiliki seorang guru diharapkan mampu memilih model pembelajaran yang tepat agar peserta didik menguasai pembelajaran sesuai dengan target yang akan dicapai dalam kurikulum.

Disisi lain diketahui bahwa, kemampuan pemecahan masalah peserta didik masih tergolong rendah khususnya di SMP Negeri 1 Pulau Panggung. Hal ini dapat dilihat pada tes kemampuan pemecahan masalah peserta didik yang telah dilakukan pada kelas VIII.A di SMP Negeri 1 Pulau Panggung. Nilai tersebut dapat dilihat dalam tabel seperti berikut:

\section{Tabel 1.1}

Data Nilai Tes Kemampuan Pemecahan Masalah Peserta Didik Semester Ganjil Kelas VIII.A

\begin{tabular}{ccccc}
\hline \multirow{2}{*}{ NO } & \multirow{2}{*}{ KELAS } & \multicolumn{2}{c}{ Nilai $(\mathrm{x})$} & Jumlah \\
\cline { 3 - 4 } & & $\mathrm{x}<75$ & $\mathrm{x} \geq 75$ & \\
\hline 1 & Kelas VIII.A & 23 & 9 & 32
\end{tabular}

Sumber: Hasil Observasi Tes Kemampuan Pemecahan Masalah Matematik Peserta Didik Kelas VIII.A SMPN 1 Pulau Panggung, Tanggal 9 Januari 2017 
Dari hasil tes kemampuan pemecahan masalah tersebut, mengindikasikan bahwa kemampuan pemecahan masalah peserta didik masihlah kurang. Sehingga perlu dicari formula yang tepat agar kemampuan tersebut dapat dikuasai oleh peserta didik khususnya peserta didik SMPN 1 Pulau Panggung.

Dari hasil observasi, dapat diketahui bahwasanya dapa proses pembelajaran di SMPN 1 Pulau Panggung, guru masih menggunakan model pembelajaran yang cenderung monoton. Sebab pembelajaran yang dilakukan sehari-hari masih menggunakan model konvensional. Hal ini menyebabkan peserta didik seringkali merasa sulit belajar matematika bahkan cenderung bosan mengikuti proses belajar mengajar di kelas serta banyak peserta didik kurang memiliki motivasi belajar. Selain itu, salah satu faktor kesulitan dalam memecahkan masalah matematika tidak terlepas dari model pembelajaran yang tidak sesuai dengan pembelajaran matematika (Wulandari, Mujib, \& Ganda Putra, 2016). Pemilihan model pembelajaran yang tepat diduga dapat membantu peserta didik menguasai kemampuan pemecahan masalah dengan baik.

Memahami masalah di atas, maka peneliti mencoba menerapkan model pembelajaran Kontekstual berbantuan Hands On Activity sebagai salah satu alternatif strategi pembelajaran, sehingga mempermudah peserta didik untuk menerima materi yang akan di sajikan, dengan demikian akan memberi rasa senang bagi peserta didik dalam belajar matematika.

Elaine mendefinisikan pembelajaran kontekstual adalah sebuah sistem yang merangsang otak untuk menyusun pola-pola yang mewujudkan makna. Lebih lanjut, Elaine mengatakan bahwa pembelajaran kontekstual adalah suatu sistem pembelajaran yang cocok dengan otak yang menghasilkan makna dengan menghubungkan muatan akademis dengan konteks dari kehidupan sehari-hari peserta didik (Rusman, 2010). Pembelajaran kontekstual diharapkan dapat membuat peserta didik menghubungkan isi mata pelajaran yang sedang dipelajari dengan konteks kehidupan sehari-hari agar pembelajaran semakin bermakna (Foeh, Marhaeni, \& Jampel, 2015). Sehingga penerapan model pembelajaran ini diharapkan dapat membuat peserta didik menguasai kemampuan pemecahan masalah matematis dengan baik. Hands on activity merupakan suatu kegiatan yang dirancang untuk melibatkan peserta didik dalam menggali informasi dan bertanya, beraktivitas dan menemukan, mengumpulkan data dan menganalisis serta membuat kesimpulan sendiri (Hidayati, Maftukhin, \& Ngazizah, 2014)). Melalui hands on activity peserta didik juga dapat memperoleh manfaat antara lain: menambah minat, motivasi, menguatkan ingatan, dapat mengatasi masalah kesulitan belajar, menghindarkan salah paham, mendapatkan umpan balik dari peserta didik serta menghubungkan yang konkrit dan yang abstrak. Hal ini juga bisa dilihat dari hasil penelitian terdahulu seperti penelitian oleh (Hidayati et al., 2014) yang menyatakan bahwa lembar penilaian unjuk kerja berbasis hands on activity dapat mengukur kreativitas siswa dan (Titi Wulandari, Sutawidjaja, \& Susiswo, 2016) yang dalam pembelajarannya menggunakan teori Van Hiele berbantuan HoA dapat meningkatkan kompetensi pengetahuan dan keterampilan pemecahan masalah, sehingga dengan adanya keterbaruan yaitu dengan pembelajaran Kontekstual berbantuan Hands On Activity diharapkan dapat memberikan peserta didik 


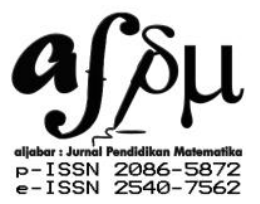

pengalaman dan kemampuan belajar yang senantiasa terkait dengan permasalahan-permasalahan aktual yang terjadi di lingkungannya. Dalam rangka mengoptimalkan pembelajaran dengan pendekatan kontekstual yang dapat mempengaruhi kemampuan pemecahan masalah matematis peserta didik, guru juga perlu memperhatikan kemandirian belajar peserta didik dalam penyelesaian permasalahan matematik.

Berdasarkan uraian di atas maka penelitian ini bertujuan untuk mengetahui pengaruh pendekatan kontekstual berbantuan Hands On Activity (HoA) terhadap kemampuan pemecahan masalah matematik.

\section{METODE PENELITIAN}

Penelitian ini merupakan penelitian kausal komparatif yang dirancang dengan desain faktorial $3 \times 1$. Populasi dalam penelitian ini adalah seluruh peserta didik kelas VIII semester genap SMP Negeri 1 Pulau Panggung TA 2016/2017 dan sampel diambil dengan teknik cluster random sampling. Sampel penelitian ini berjumlah peserta didik yang terdiri dari 96 peserta didik. Teknik pengumpulan data adalah metode dokumentasi, metode angket, dan metode tes. Instrumen penelitian terdiri atas tes pemecahan masalah matematis dan angket kemandirian belajar matematika. Uji coba instrumen angket kemandirian belajar matematika dan tes pemecahan masalah matematis dilakukan di kelas IX A dengan responden 25 peserta didik. Untuk instrumen tes pemecahan masalah mengacu pada kriteria yaitu validitas isi, daya pembeda $(\mathrm{D} \geq 0,3)$ (Budiyono, 2011) tingkat kesukaran $(0,3 \leq \mathrm{P} \leq 0,7)$ (Sudijono, 2005), dan reliabilitas $\left(r_{11} \geq 0,7\right)$ (Budiyono, 2011) dari 10 butir soal yang diujicobakan diperoleh 5 butir soal yang digunakan sebagai alat pengambil data kemampuan pemecahan masalah matematis peserta didik. Uji prasyarat analisis yaitu uji normalitas dengan Lilliefors dan uji homogenitas dengan uji Bartlett. Uji analisis data yang digunakan yaitu analisis variansi dua jalan dengan sel tak sama (Budiyono, 2009).

\section{HASIL PENELITIAN DAN PEMBAHASAN}

Pembelajaran dengan menggunakan pendekatan kontekstual berbantuan Hands On Activity dapat mendorong peserta didik berperan secara aktif untuk menemukan hubungan materi yang dipelajari dengan kehidupan nyata sehingga pembelajaran menjadi lebih bermakna dan nyata. Berdasarkan penelitian yang telah dilakukan oleh (Mulhamah \& Putrawangsa, 2016) menyatakan bahwa penerapan pendekatan pembelajaran kontekstual dapat meningkatkan kemampuan pemecahan masalah peserta didik pada mata pelajaran matematika. Peserta didik yang diajarkan dengan menggunakan pendekatan kontekstual memiliki kemampuan pemecahan masalah lebih baik daripada peserta didik yang diajarkan dengan menggunakan model pembelajaran konvensional/metode ceramah.

Salah satu penyebab skor rata-rata hasil tes kemampuan pemecahan masalah matematika peserta didik dari kelas eksperimen dan kelas kontrol tersebut berbeda-beda adalah proses 
pembelajaran menggunakan pendekatan kontekstual berbantuan Hands On Activity menjadikan peserta didik belajar dengan optimal sehingga materi dapat diingat peserta didik lebih tinggi dan meningkatkan kemampuan peserta didik dalam memecahkan masalah matematika. Sedangkan proses pembelajaran menggunakan metode ceramah menekankan kepada situasi peneliti/pendidik mengajar bukan situasi peserta didik belajar. Kondisi ini menyebabkan peserta didik kurang mampu untuk mengingat materi serta kurang mampu menyalesaikan masalah-masalah matematika.

Kemampuan pemecahan masalah maetematika peserta didik rendah disebabkan karena rendahnya kemandirian belajar peserta didik terhadap matematika. Tinggi rendahnya kemandirian belajar peserta didik terhadap matematika sering kali dikaitkan dengan keberhasilan dan kegagalannya dalam hasil belajar. Peserta didik yang memiliki kemandirian belajar tinggi dan sedang selalu berusaha menyelesaikan tugasnya dengan baik dan mampu menyelesaikan masalah-masalah matematika. Hal ini dapat disimpulkan bahwa kemandirian belajar peserta didik merupakan faktor yang sangat berpengaruh terhadap kemampuan pemecahan masalah matematika peserta didik.

Mengingat setiap peserta didik memiliki kemampuan berfikir yang berbeda dan adanya kesulitan peserta dididk dalam memecahkan suatu masalah, maka dengan keterampilan dan keahlian yang dimiliki seorang pendidik, diharapkan mampu memilih nodel pembelajaran yang tepat agar peserta didik dapat menguasai pembelajaran sesuai dengan target yang akan dicapai kurikulum.

Setelah hasil tes akhir diperoleh, maka selanjutnya dilakukanlah uji normalitas dengan menggunakan uji Lilifors dan uji homogenitas dengan menggunakan uji Bartlet untuk melihat kenormalan dan kehomogenan kelas tersebut. Berdasarkan hasil pengujian normalitas menunjukkan bahwa sampel berasal dari populasi yang berdristibusi normal. Dan hasil pengujian homogenitas menunjukkan bahwa sampel berasal dari populasi yang memiliki variansi yang sama (homogen).

Setelah diketahui data berasal dari populasi berdistribusi normal dan dari populasi yang sama (homogen), maka dapat dilanjutkan uji hipotesis dengan menggunakan uji parametrik yaitu uji analisis variansi (ANAVA). Berdasarkan hasil pengujian hipotesis menggunakan uji ANAVA dua jalan dengan sel tak sama diperoleh bahwa terdapat pengaruh antara pendekatan pembelajaran kontekstual berbantuan Hands On Activity, pendekatan pembelajaran kontekstual dan metode ceramah terhadap kemampuan pemecahan masalah matematika karena $F_{\text {hitung }}>F_{\text {tabel }}$ yang menunjukkan bahwa $\mathrm{H}_{0}$ ditolak. Selain itu, dengan melakukan uji komparasi ganda antar baris didapat bahwa rerata yang diperoleh dari perlakuan pembelajaran dengan menggunakan pendekatan pembelajaran kontekstual berbantuan Hands On Activity lebih baik daripada perlakuan pembelajaran dengan menggunakan pendekatan pembelajaran kontekstual dan metode ceramah. Begitupun untuk rerata yang diperoleh dari perlakuan 
pembelajaran dengan menggunakan pendekatan pembelajaran kontekstual lebih baik daripada perlakuan pembelajaran dengan menggunakan metode ceramah. Dengan demikian menunjukkan bahwa kemampuan pemecahan masalah matematik peserta didik yang diajarkan dengan menggunakan pendekatan pembelajaran kontekstual berbantuan Hands On Activity lebih baik daripada peserta didik yang diajarkan dengan menggunakan pendekatan pembelajaran kontekstual maupun metode ceramah. Sedangkan peserta didik yang diajarkan dengan menggunakan model pembelajaran kontekstual menghasilkan kemampuan pemecahan masalah yang lebih baik daripada peserta didik yang diajarkan dengan menggunakan metode ceramah.

Adapun faktor-faktor yang mempengaruhi keberhasilan kemampuan pemecahan masalah matematika peserta didik dikelas eksperimen dengan perlakuan pembelajaran menggunakan pendekatan pembelajaran kontekstual berbantuan Hands On Activity lebih baik dari kelas eksperimen dengan perlakuan pembelajaran menggunakan pendekatan pembelajaran kontekstual maupun di kelas kontrol dengan perlakuan menggunakan metode ceramah yaitu:

a) Kebebasan peserta didik untuk membangun pengetahuan dalam proses pembelajaran membuat peserta didik kelas eksperimen lebih siap untuk belajar dengan kemampuan dan kemandirian belajar mereka tanpa diberikan pengetahuan langsung oleh pendidik.

b) Lembar Kegiatan Kelompok (LKK) yang sangat menunjang perkembanagan pengetahuannya, sehingga peserta didik lebih mudah mengkaji pengetahuannya dan lebih terarah.

c) Penerapan pendekatan kontekstual berbantuan Hands On Activity menjadikan peserta didik lebih aktif dan termotivasi untuk belajar karena peserta didik dapat meningkatkan kemampuannya dalam proses pembelajaran, sehingga peserta didik dapat menemukan pemecahannya sendiri.

d) Peserta didik dapat memusatkan pada kesalahan yang ia lakukan, sehingga peserta didik mampu untuk memahami materi yang sedang dipelajari dan dapat meminimalisir terhadap kesalahan karena pendidik membahas bersama terhadap terhadap kesalahan-kesalahan yang dihadapi peserta didik dalam memahami materi dengan memberikan solusi untuk menghadapi kesulitan-kesulitan yang ada.

Hal ini menunjukkan bahwa penggunaan pendekatan pembelajaran kontekstual berbantuan Hands On Activity dalam pembelajaran matematika berpengaruh terhadap kemampuan pemecahan masalah matematika ditinjau dari kemandirian belajar peserta didik. Hal ini sejalan dengan penelitian yang telah dilakukan oleh (Mulhamah \& Putrawangsa, 2016) menyatakan bahwa penerapan pendekatan pembelajaran kontekstual dapat meningkatkan kemampuan pemecahan masalah peserta didik pada mata pelajaran matematika. 


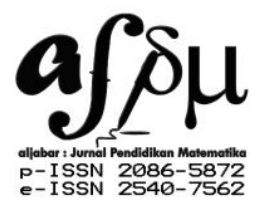

Al-Jabar: Jurnal Pendidikan Matematika
Vol. 8, No. 1, 2017, Hal $73-80$

\section{SIMPULAN DAN SARAN}

Berdasarkan hasil analisis dan pembahasan diperoleh hasil bahwa terdapat pengaruh pendekatan Kontekstual berbantuan Hands On Activity terhadap kemampuan pemecahan masalah matematik. Peserta didik dengan perlakuan pembelajaran menggunakan model pembelajaran kontekstual berbantuan Hands On Activity, memiliki kemampuan pemecahan masalah matematika lebih baik dibandingkan dengan peserta didik dengan perlakuan pembelajaran menggunakan model pembelajaran kontekstual maupun model pembelajaran konvensional/metode ceramah baik secara umum maupaun ditinjau pada masing-masing kategori kemandirian belajar matematik peserta didik.

Berdasarkan hasil penelitian dan beberapa temuan dilapangan, penulis menyarankan untuk Lembaga pendidikan khususnya SMP Negeri 1 Pulau Panggung dapat menerapkan model pembelajaran kontekstual berbantuan Hands On Activity untuk melatih keaktifan dan kemandirian belajar peserta didik dalam proses pembelajaran, model pembelajaran kontekstual berbantuan Hands On Activity dapat meningkatkan keterlibatan peserta didik dalam aktifitas pembelajaran. Oleh karena itu disarankan kepada pendidik untuk menerapkan model pembelajaran kontekstual berbantuan Hands On Activity dalam pembelajaran matematika, sebagai alternatif dalam pembelajaran yang dapat meningkatkan kemampuan pemecahan masalah matematika peserta didik. Bagi penelitian selanjutnya disarankan untuk melihat peningkatan setiap indikator kemampuan pemecahan masalah matematika dan kemampuan lainnya yang bisa diterapkan melalui model pembelajaran kontekstual berbantuan Hands On Activity. Semoga apa yang diteliti dapat memberikan manfaat serta sumbangan pemikiran baik pendidik pada umumnya dan penulis pada khususnya.

\section{DAFTAR PUSTAKA}

Budiyono. (2009). Statistika Untuk Penelitian. Surakarta: UNS Press.

Budiyono. (2011). Penilaian Hasil Belajar. Surakarta: UNS Press.

Foeh, Y., Marhaeni, A. N., \& Jampel, I. N. (2015). Pengaruh Model Pembelajaran Kontekstual Terhadap Hasil Belajar Pendidikan Agama Kristen Dengankovariabel Motivasi Belajar Dan Sikap Religius Pada Siswa Kelas Xi Sma N 7 Kupang Tahun Pelajaran 2014/2015. EJournal Program Pascasarjana Universitas Pendidikan Ganesha, 5(1), 1-11.

Hidayati, A., Maftukhin, A., \& Ngazizah, N. (2014). Pengembangan Penilaian Unjuk Kerja Berbasis Hands On Activity untuk Mengukur Kreativitas pada Siswa Kelas X SMA Negeri 5 Purworejo Tahun Pelajaran 2013 / 2014. Radiasi, 5(2), 50-52.

Mawaddah, S., \& Anisah, H. (2015). Kemampuan Pemecahan Masalah Matematis Peserta didik Pada Pembelajaran Matematika Dengan Menggunakan Model Pembelajaran Generatif (GENERATIVE LEARNING) di SMP. EDU-MAT Jurnal Pendidikan Matematika, 3(2), 


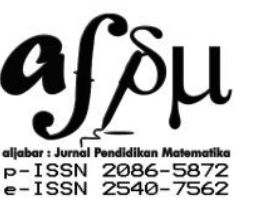

Al-Jabar: Jurnal Pendidikan Matematika

Vol. 8, No. 1, 2017, Hal 73 - 80

$166-175$.

Mulhamah, \& Putrawangsa, S. (2016). Penerapan Pembelajaran Kontekstual dalam Meningkatkan Kemampuan Pemecahan Masalah Matematika. Jurnal Pendidikan Matematika, 10(1), 58-80.

Rusman. (2010). Model-model Pembelajaran Mengembangkan Profesionalisme Guru. Jakarta: Raja Grafindo Persada.

Sudijono, A. (2005). Pengantar Evaluasi Pendidikan. Jakarta: Raja Grafindo Persada.

Titi Wulandari, R., Sutawidjaja, A., \& Susiswo. (2016). Pembelajaran Berdasarkan Teori Van Hiele Berbantuan Hands on Activity (Hoa) Untuk Meningkatkan Kompetensi Pengetahuan Dan Keterampilan Pemecahan Masalah. Jurnal Pendidikan: Teori, Penelitian, Dan Pengembangan, 1(8), 1479-1486.

Wulandari, P., Mujib, \& Ganda Putra, F. (2016). Pengaruh Model Pembelajaran Investigasi Kelompok Berbantuan Perangkat Lunak Maple Terhadap Kemampuan Pemecahan Masalah Matematis. Al-Jabar, 7(1), 136-143. 